\title{
PEMAHAMAN GURU BIMBINGAN DAN KONSELING TINGKAT SMP TENTANG BIMBINGAN DAN KONSELING KOMPREHENSIF
}

\author{
Caraka Putra Bhakti ${ }^{1}$, Agus Ria Kumara ${ }^{2}$, Nindiya Eka Safitri ${ }^{3}$ \\ ${ }^{1}$ Program Studi Bimbingan dan Konseling Universitas Ahmad Dahlan Yogyakarta \\ caraka.pb@bk.uad.ac.id, \\ ${ }^{2}$ Program Studi Bimbingan dan Konseling Universitas Ahmad Dahlan Yogyakarta \\ agus.kumara@bk.uad.ac.id, \\ ${ }^{3}$ Program Studi Bimbingan dan Konseling Universitas Ahmad Dahlan Yogyakarta \\ nindiya1315001306@webmail.uad.ac.id
}

\begin{abstract}
Abstrak
Bimbingan dan konseling komprehensif sebagai bagian integral pendidikan memiliki peran penting dalam pengembangan potensi siswa guna menghadapi kehidupan MEA yang kompleks. Guru BK hendaknya memahami konsep teoritis dan praksis bimbingan dan konseling komprehensif di sekolah. Ironisnya, beberapa guru BK belum paham tentang hal tersebut. Penelitian ini bertujuan untuk mengetahui tingkat pemahaman guru BK SMP tentang program bimbingan dan konseling komprehensif. Metode yang digunakan adalah deskriptif kuantitatif dengan subjek guru BK SMP se-Kabupaten Gunungkidul, DIY sejumlah 44 orang. Instrumen yang digunakan berupa tes pemahaman jenis multiple choice, dengan teknik analisis deskriptif. Hasil penelitian menunjukkan bahwa rata-rata pemahaman guru bimbingan dan konseling tentang program bimbingan dan konseling sebesar 50 poin dan tertinggi sebesar 100 poin. Hal ini menunjukkan bahwa belum semua guru BK SMP di Kabupaten Gunungkidul memiliki pemahaman yang baik tentang program bimbingan dan konseling komprehensif.
\end{abstract}

Kata kunci: bimbingan dan konseling, komprehensif, pemahaman

\begin{abstract}
Comprehensive guidance and counseling as an integral part of education has an important role to develop of student potential in order to face the complex life of AEC. Guidance and counseling teachers should understand the theoretical and practical concepts of guidance and counseling comprehensive in schools. Ironically, some of the guidance and counseling teachers do not understand about it. The purpose of this research is to determine the level of the guidance and counseling teacher's understanding about comprehensive guidance and counseling program. The method used is quantitative descriptive which the subjects are guidance and counseling teacher in Junior High School in Gunungkidul District, DIY. The number of subject in this resserch are of 44 people. This research is multiple choice tests type, with descriptive analysis techniques. The results showed that the average of guidance and counseling teachers understanding about guidance and counseling program was 50 points and the highest was 100 points. This shows that not all guidance and counseling teachers in Junior High School in Gunungkidul have a good understanding of the comprehensive guidance and counseling program.
\end{abstract}

Keywords: guidance and counseling, comprehensive, understanding 


\section{PENDAHULUAN}

Saat ini, bangsa Indonesia sedang dihadapkan pada tuntutan Masyarakat Ekonomi ASEAN (MEA). Masyarakat Ekonomi ASEAN (MEA) merupakan suatu bentuk target pencapaian yang digagas oleh ASEAN untuk menjadikan ASEAN sebagai kawasan pergerakan bebas barang, jasa, investasi, tenaga kerja terampil, dan arus modal yang lebih bebas. Di era MEA, situasi kehidupan semakin kompleks, penuh peluang dan tantangan. Masyarakat dunia dituntut untuk memiliki kompetensi agar dapat berkembang secara dinamis, produktif dan mandiri (Irvan \& Nindiya, 2016: 157). Salah satu tuntutan dalam MEA adalah tersedianya SDM yang bermutu.

Pemenuhan tuntutan ini tidak terlepas dari peran pendidikan. SDM yang bermutu dapat tercapai melalui pendidikan yang bermutu (Caraka \& Nindiya, 2015: 55). Hal ini sejalan dengan pernyataan Juntika (2011) bahwa pendidikan yang bermutu adalah pendidikan yang mampu mengantarkan peserta didik memenuhi kebutuhannya, baik saat ini maupun di masa yang akan datang. Menurut Tilaar dalam Juntika (2011: 13), untuk mencapai hasil pendidikan yang bermutu, diperlukan proses pendidikan yang bermutu. Kemampuan yang diberikan melalui proses pendidikan bermutu tidak hanya menyangkut aspek akademis saja, tetapi juga menyangkut berbagai aspek kehidupan yang komprehensif yakni perkembangan pribadi, sosial, kematangan individu, dan sistem nilai.

\begin{abstract}
Bimbingan dan konseling sebagai bagian integral proses pendidikan memiliki kontribusi dalam penyiapan SDM bermutu. Dalam perspektif bimbingan dan konseling, peserta didik merupakan individu sedang berada dalam proses berkembang atau menjadi (becoming), yaitu berkembang ke arah kematangan atau kemandirian. Untuk mencapai kematangan, individu memerlukan bimbingan, karena masih kurang memahami kemampuan dirinya, lingkungannya dan pengalaman untuk mencapai kehidupan yang bermutu. Oleh karena itu, diperlukan layanan bimbingan dan konseling yang tidak hanya memandang masalah dari sudut pandang peserta didik tetapi juga memperhatikan faktor-faktor dari lingkungan sekitar peserta didik (Caraka \& Nindiya, 2015: 55).
\end{abstract}

Di sini, terlihat bahwa bimbingan dan konseling yang berfokus pada perkembangan peserta didik sangat urgen. Sebagaimana pendapat Sutoyo, dkk (2015: 48) bahwa BK perkembangan berbicara "fokus" atau pusat perhatian membantu perkembangan potensi, sedangkan BK komprehensif bicara "cakupan aspek" yang dikembangkan yang menyeluruh (komprehensif), artinya bukan hanya aspek jasmani saja, atau rohani saja, tetapi menyeluruh". Orientasi dari BK perkembangan adalah terwujudnya perkembangan yang optimal pada diri siswa. Sitti \& Caraka (2016: 270) menyatakan bahwa "optimum development is not limited to the achievement of achievement in accordance with the intellectual capacity and interest, but as a developmental condition that 
allow leaners are able to make choice and decisions in responsibility and adaptability to the dynamics of their life."

Fajar Santoadi (2010: 23) mengungkapkan bahwa secara implisit bimbingan dan konseling saat ini sudah berorientasi perkembangan. Semenjak tahun 1970-an, terutama di negara-negara maju (misalnya negara-negara bagian Amerika) mulai berkembang model program bimbingan dan konseling komprehensif. Sementara itu, Dede (2013: 128) mengungkapkan bahwa model bimbingan dan konseling komprehensif dirancang untuk merespons berbagai persoalan yang dihadapi oleh konselor sekolah. Model ini dikembangkan berdasarkan berbagai hasil kajian teori, dan hasil penelitian yang telah dilaksanankan oleh ASCA tentang program bimbingan dan konseling dan profesi konselor sekolah. Model ini merupakan alternatif model bimbingan dan konseling yang memberikan kesempatan bagi akademisi dan praktisi konseling untuk meningkatkan layanan bimbingan dan konseling di sekolah.

Meskipun model ini diadopsi
dari model ASCA yang
dikembangkan untuk mengatasi
masalah yang dialami oleh
bimbingan dan konseling di Amerika
Serikat, namun model ini dapat
diadaptasikan di Indonesia. Model
bimbingan dan konseling
komprehensif memberikan
kesempatan bagi ilmu bimbingan dan
konseling di Indonesia melakukan
perubahan ke arah yang lebih baik.
Adaptasi model bimbingan dan
konseling komprehensif memberi

peluang kepada konselor untuk mneunjukkan kinerjanya, sehingga profesi bimbingan dan konseling mendapatkan pengakuan di masyarakat.

Untuk dapat mengadopsi model bimbingan dan konseling komprehensif, permerintah Indoensia mengeluarkan Permendikbud Nomor 111 Tahun 2014 tentang Bimbingan dan Konseling Pada Pendidikan Dasar dan Pendidikan Menengah. Substansi dari permendikbud ini meliputi komponen program, bidang layanan, struktur program layanan, serta kegiatan dan alokasi waktu. Permendikbud tidak secara eksplisit membahas tentang bimbingan dan konseling komprehensif, tetapi dilihat dari substansinya ini menunjukkan versi model bimbingan dan konseling komprehensif. Untuk dapat meningkatkan mutu layanan dan kinerja, guru BK perlu merujuk pada Permendikbud ini.

Dengan demikian, guru BK/konselor sangat diharapkan mampu mengembangkan program bimbingan dan konseling sesuai substansi permendikbud di atas. Namun, kinerja konselor/guru BK saat ini belum sejalan dengan apa yang diharapkan. Di luar sana masih banyak guru BK/konselor yang belum paham akan teori dan praksis bimbingan dan konseling di sekolah yang benar, terlebih kaitannya dengan program bimbingan dan konseling komprehensif. Dari perspektif tersebut di atas, maka peneliti melakukan penelitian tentang pemahaman guru BK tingkat SMP tentang bimbingan dan konseling komprehensif. 


\section{METODE PENELITIAN}

Dalam penelitian ini, jenis penelitian yang dilakukan adalah jenis penelitian deskriptif. Menurut Suharsimi (2013:3),“ Penelitian deskriptif adalah penelitian yang dimaksudkan untuk menyelidiki keadaan, kondisi, atau hal-hal lainlain yang sudah disebutkan, yang hasilnya dipaparkan dalam bentuk laporan penelitian". Adapun peneliti melaksanakan penelitian di seluruh SMP di Kabupaten Gunungkidul, Provinsi Daerah Istimewa Yogyakarta. Penelitian telah dilaksanakan oleh peneliti pada bulan Agustus sampai dengan November tahun 2016.

Subjek penelitian ini adalah guru bimbingan dan konseling di seluruh SMP di Kabupaten Gunungkidul yang berjumlah 44 guru. Objek penelitian ini adalah tentang profil tingkat pemahaman guru bimbingan dan konseling tentang penyusunan program bimbingan dan konseling komprehensif di SMP. Sedangkan, teknik pengumpulan data yang digunakan menggunakan teknik tes, dimana instrumen yang digunakan adalah berupa tes pemahaman berbentuk multiple choice dengan 4 (empat) alternatif jawaban. Selanjutnya, teknik analisis data yang digunakan menggunakan teknik analisis data deskriptif kuantitatif.

\section{HASIL DAN PEMBAHASAN}

Hasil penyebaran tes pemahaman kepada guru berada dalam rentang dari nol sampai 100 . Hal ini berarti semakin mendekati nilai 100 maka nilai yang diperoleh guru semakin tinggi. Dapat diketahui besarnya nilai rata-rata sebesar 77,37, hal ini berarti mendekati ke nilai maximal. Berikut ini adalah tabel statistik deskriptif pemahaman guru BK tentang program bimbingan dan konseling komprehensif.

Tabel 1. Statistik Deskriptif Pemahaman Guru BK

\begin{tabular}{lr}
\hline \multicolumn{2}{c}{ Statistics } \\
\hline Nilai & \multicolumn{1}{l}{ Valid } \\
\cline { 2 - 2 } $\mathrm{N}$ & Missing \\
\hline Mean & 77,3864 \\
\hline Std. Error of Mean & 1,89224 \\
\hline Median & 80,0000 \\
\hline Mode & $80,00^{\mathrm{a}}$ \\
\hline Std. Deviation & 12,55169 \\
\hline Variance & 157,545 \\
\hline Skewness &,- 443 \\
\hline Std. Error of Skewness &, 357 \\
\hline Kurtosis &,- 651 \\
\hline
\end{tabular}




\begin{tabular}{|c|c|c|}
\hline \multicolumn{2}{|c|}{ Std. Error of Kurtosis } & ,702 \\
\hline \multicolumn{2}{|l|}{ Range } & 50,00 \\
\hline \multicolumn{2}{|l|}{ Minimum } & 50,00 \\
\hline \multicolumn{2}{|l|}{ Maximum } & 100,00 \\
\hline \multicolumn{2}{|l|}{ Sum } & 3405,00 \\
\hline \multirow{3}{*}{ Percentiles } & 25 & 66,2500 \\
\hline & 50 & 80,0000 \\
\hline & 75 & 90,0000 \\
\hline
\end{tabular}

a. Multiple modes exist. The smallest value is shown

Berdasarkan tabel statistik deskriptif nampak nilai maksimal sebesar 100, minimum 50. Hasil ini menunjukkan tingkat pemahaman guru BK sangat bervariasi. Ada sejumlah guru BK yang memiliki pemahaman tinggi dan adapula guru BK yang memiliki pemahaman rendah. Nilai median sebesar 80, menunjukkan guru BK yang memiliki kemampuan menengah mendapatkan nilai 80. Demikian juga dengan nilai mode yakni 80 sehingga nilai 80 merupakan nilai yang paling banyak didapatkan oleh para guru. Nilai ini relatif bagus karena dengan rentang nilai 50 sampai 100 , kemudian nilai tengahnya 80 yang menunjukkan rata-rata atas.

Hasil penelitan terkait pemahaman guru BK SMP tentang program bimbingan dan konseling komprehensif dapat ditunjukkan dengan grafik berikut.

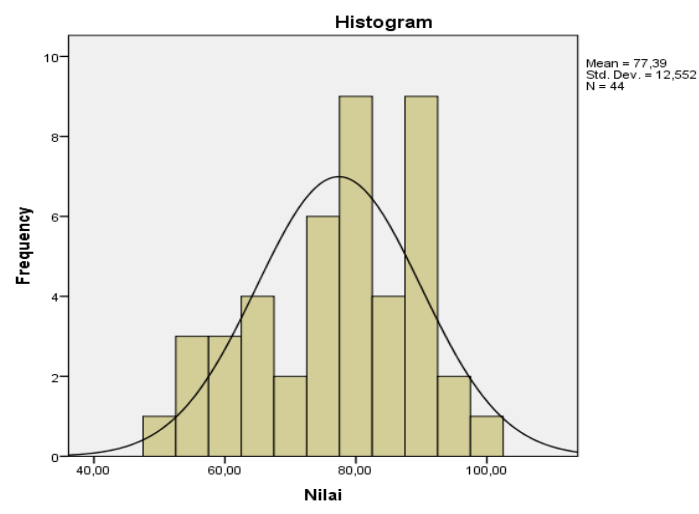

Grafik 1. Histogram Nilai Pemahanan Guru BK

Berdasarkan grafik di atas, dapat diketahui bahwa nilai skewness menunjukkan ada kecenderungan kurva normal juling positif (lihat grafik histogram). Hal ini berarti jumlah peserta workshop yang mendapatkan nilai di atas ukuran pusat (mean, median, modus) cukup banyak. Sehingga meskipun terdapat nilai prestasi yang di bawah, akan 
tetapi peserta yang mendapatkan nilai di atas ukuran pusat lebih banyak. Bentuk kurva normal yang terbentuk dari data cukup baik, sehingga dapat menggambarkan kondisi populasi.

Berdasarkan hasil input data penelitian, nilai pemahaman guru BK sangat beragam, dengan rentang yang bervariasi pula. Berikut ini adalah tebel yang menunjukkan distribusi frekuensi nilai pemahaman guru BK SMP tentang program bimbingan dan konseling komprehensif.

Tabel 1. Distribusi Frekuensi Nilai Pemahaman Guru BK

\begin{tabular}{cccc}
\hline Nilai & Frequency & Percent & $\begin{array}{c}\text { Cumulative } \\
\text { Percent }\end{array}$ \\
\hline 50,00 & 1 & 2,3 & 2,3 \\
\hline 55,00 & 3 & 6,8 & 9,1 \\
\hline 60,00 & 3 & 6,8 & 15,9 \\
\hline 65,00 & 4 & 9,1 & 25,0 \\
\hline 70,00 & 2 & 4,5 & 29,5 \\
\hline 75,00 & 6 & 13,6 & 43,2 \\
\hline 80,00 & 9 & 20,5 & 63,6 \\
\hline 85,00 & 4 & 9,1 & 72,7 \\
\hline 90,00 & 9 & 20,5 & 93,2 \\
\hline 95,00 & 2 & 4,5 & 97,7 \\
\hline 100,00 & 1 & 2,3 & 100,0 \\
\hline Total & 44 & 100,0 & \\
\hline
\end{tabular}

Berdasarkan tabel di atas, dapat diketahui dari bahwa nilai kumulatif kurang atau sama dengan 75 sebanyak 43,2\%. Artinya ada $43,2 \%$ guru yang mendapatkan nilai $\leq 75$. Frekuensi yang paling banyak adalah 9, yakni dengan nilai 80 dan 90, yang dapat disebut multi modus. Guru BK yang mendapatkan nilai terendah 50 dan tertinggi 100, hanya satu orang $(2,3 \%)$. Hal ini menunjukkan ada guru BK yang memiliki pemahaman tentang program bimbingan dan konseling komprehensif dalam kategori rendah dan adapula guru BK yang memiliki pemahaman kategori tinggi.

Untuk lebih memperjelas tabel di atas, secara keseluruhan tingkat pemahaman guru BK tentang program bimbingan dan konseling komprehensif di Kabupaten Gunungkidul dapat digambarkan sebagai berikut. 


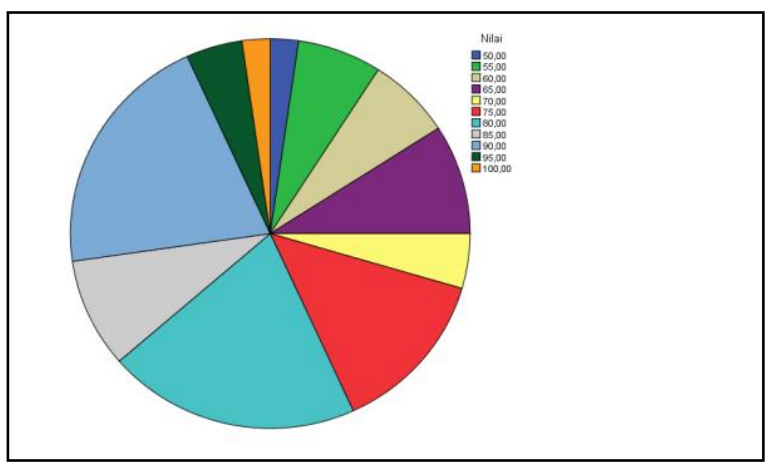

Grafik 1. Prosentase Pemahaman Guru BK tentang Program BK Komprehensif

Hasil penelitian di atas berkaitan dengan adanya kebijakan baru yaitu Permendikbud Nomor 111 Tahun 2014 tentang Bimbingan dan Konseling Pada Pendidikan Dasar dan Menengah. Bagi guru $\mathrm{BK} /$ konselor di sekolah, pemberlakuan permendikbud ini berdampak signifikan pada administrasi dan prosedur pelayanan bimbingan dan konseling. Dalam konteks pelayanan bimbingan dan konseling terjadi perubahan paradigma baru, termasuk dalam penyusunan program bimbingan dan konseling berbasis komprehensif. Guru BK/konselor dituntut untuk memahami secara lebih mendalam tentang konsep dasar teoritis dan praksis bimbingan dan konseling komprehensif termasuk cara penyusunan program bimbingan dan konseling komprehensif sesuai dengan tugas perkembangan peserta didik pada jenjang sekolah tertentu.

Hasil penelitian menunjukkan bahwa pemahaman guru BK tentang program bimbingan dan konseling komprehensif masih dalam kategori sedang. Berdasarkan hasil penelitian yang sedemikian rupa, maka upaya yang dapat dilakukan oleh guru bimbingan dan konseling untuk meningkatkan pemahaman tentang Program bimbingan dan konseling komprehensif ialah melalui Musyawarah Guru Bimbingan dan Konseling (MGBK) , diskusi, seminar dan workshop ataupun bisa membaca literatur yang berkaitan tentang Program bimbingan dan konseling komprehensif, serta hal yang paling penting dan paling efektif selain dari usaha di atas yaitu dengan cara melakukan praktik penyusunan program bimbingan dan konseling komprehensif di sekolah yang bapak/ibu guru tempati.

\section{SIMPULAN}

Hasil penelitian tentang pemahaman dan kebutuhan akan program bimbingan dan konseling komprehensif, menunjukkan hasil bahwa rata-rata pemahaman guru bimbingan dan konseling akan program bimbingan dan konseling sebesar 50 poin dan tertinggi sebesar 100 poin. Hal ini menunjukkan bahwa belum semua guru BK SMP di Kabupaten Gunungkidul memiliki pemahaman yang baik tentang program bimbingan dan konseling komprehensif. Berdasarkan hasil ini, 
maka perlu dilakukan peningkatan akan pemahaman tentang bimbingan dan konseling komprehensif. Adapun beberapa hal yang dapat dilakukan untuk dapat meningkatlkan pemahaman terkait hal ini, diantaranya yaitu penyelenggaraan seminar program BK komprehensif, penyelenggaraan workshop penyusunan program BK komprehensif, pengembangan modul penyusunan program BK komprehensif dan pengembangan model program BK komprehensif. Hasil dari penelitian ini diharapkan dapat digunakan sebagai bahan kajian keilmuan bimbingan dan konseling serta sebahai bahan kajian pembanding pada penelitian selanjutnya.

\section{DAFTAR PUSTAKA}

American School Counselor Association. (2012). The ASCA National Model: A Frame work For School Counseling Program. Third Edition. Alexandria, VA: Author.

Bhakti, C. P. (2015). BIMBINGAN DAN KONSELING KOMPREHENSIF: DARI PARADIGMA MENUJU AKSI. Jurnal Fokus Konseling, 1(2), 93-106.

Budhi Handaka, I., \& Eka Safitri, N. (2016, March). PEMANFAATAN METODE EXPERIENTIAL

\begin{tabular}{|c|c|}
\hline \multicolumn{2}{|c|}{ LEARNING $\quad$ UNTUK } \\
\hline MENINGKATKAN & \\
\hline KETERAMPILAN & \\
\hline BERPIKIR KRITIS & \\
\hline DALAM & \\
\hline
\end{tabular}

In PROSIDING SEMINAR NASIONAL "Optimalisasi Active Learning dan Character Building dalam Meningkatkan Daya Saing Bangsa di Era Masyarakat Ekonomi Asean (MEA)" (pp. 157-164). Prodi Pendidikan Guru Sekolah Dasar dan Prodi Bimbingan dan Konseling.

Caraka, P. B., \& Nindiya, E. S. (2015). Implementasi Permendikbud RI Nomor 111 Tahun $2014 \quad$ Dalam Pengembangan Layanan BK di Sekolah Menengah. In Prosiding Seminar Nasional Bimbingan Dan Konseling (pp. 55-61).

Hasan, S. U. N., \& Bhakti, C. P. (2016). Guidance and Counselling: A Comparison between Indonesia and Malaysia. Scientific Journal of PPI-UKM, 3(6), 267-271.

Hidayat, Dede Rahmat. (2013). Bimbingan Konseling:

Kesehatan Mental Di sekolah. Bandung : Remaja Rosda Karya.

Juntika. (2011). Membangun Peradaban Bangsa Indonesia Melalui Pendidikan dan Komprehensif Bermutu. Disampaikan dalam pidato Pengukuhan Prof. Dr. $\mathrm{H}$. Juntika, M.Pd sebagai Guru Besar/Profesor dalam Bidang Bimbingan dan Konseling Pada Fakultas Ilmu Pendidikan Universitas Pendidikan Indonesia. 
Peraturan Menteri Pendidikan dan Kebudayaan RI Nomor 111 Tahun 2014 tentang Bimbingan dan Konseling Pada Pendidikan Dasar dan Pendidikan Menengah.

Santoadi, Fajar. (2010). Manajeman Bimbingan dan Konseling Komprehensif. Yogyakarta : Universitas Sanata Dharma.
Suharsimi, Arikunto. (2013). Prosedur Penelitian: Suatu Pendekatan Praktik. Jakarta: Rineka Cipta.

Sutoyo, Anwar dkk. (2015). Bimbingan dan Konseling Perkembangan. Semarang: Pasca Sarjana Bimbingan dan Konseling UNNES. 